\title{
Grammatical Equivalence of Animal Science Terms Translation
}

\author{
I Gusti Agung Istri Aryani ${ }^{1}$, I Nengah Sudipa ${ }^{1}$, Ida Bagus Putra Yadnya ${ }^{1} \&$ Ni Made Dhanawaty ${ }^{1}$ \\ ${ }^{1}$ Faculty of Arts, Udayana University, Indonesia \\ Correspondence: I Gusti Agung Istri Aryani, Faculty of Arts, Udayana University, Indonesia.
}

Received: April 20, 2019 Accepted: May 19, 2019 Online Published: May 22, 2019

doi: 10.5539/elt.v12n6p199 URL: https://doi.org/10.5539/elt.v12n6p199

\begin{abstract}
Translating specific language for a special subject such as animal science terms should have an understanding of the knowledge. The results of translation in their forms also give effect to their meaning in order to obtain the equivalence and adaptation from the source language (SL) into the target language (TL). This study aims at finding equivalence in the form of translation including their effect of meaning translated from English (SL) into Indonesian (TL). Qualitative method is used to analyze the translation of languages with a descriptive explanation. Both languages have their own grammatical rules which have varieties of translation, especially for the result of findings in TL. The grammatical equivalence found in numbers of nouns and noun phrases. Majorly, they were found with the suffix $-\mathrm{s}$ for the plural form in SL and translated without reduplication in TL to show their adaptation as a scientific language. In some cases, the terms in SL were translated into collective words and conjunction. It showed in scientific languages, both languages have their own rules to give equivalence of forms in SL and TL including their meaning.
\end{abstract}

Keywords: form, equivalence, noun, noun phrase

\section{Introduction}

\subsection{Translating Animal Science Terms Is Challenging}

The translation is not only concern on transferring language and finding to their closest equivalence in TL but understanding the grammatical forms including their meaning in SL and TL. This is due to the complexity of all languages in the world may differ in forms and meaning after translated. A translator of a language should have an understanding of forms in both languages in order to find the grammatical equivalences. Marcos et al. (2002) mentions that scientific translation in a special field has its own natural of laws and principles. An author who also works as a translator must recognize the cultural differences and giving respect to it. The challenges and skills require in translations for the choice of words; give respect for any preferences; the understanding of sciences and languages used in the translation; familiar of terms; and time management to complete the work. In this study, scientific translation such as animal science terms considers having a major of understanding for the languages. This is due to the terms applied in those texts are related to the transfer of knowledge to the target readers including the translator level of experiences, background, and cultural competence (Montgomery, 2009). It should not be a problem for them to translate the languages when they are experts who have the background of knowledge of the subject and have experiences for those specific terms. Romero (2014) conveys that suitable choice of terms and the decision of translator in these specialized terms is challenging because he or she should understand what is being mentioned inside the text but also the context, ensuring the review, recognizing who are the target readers for the purpose of obtaining a high quality of translation. In this study of animal science forms, cross linguistics differences are forms which mainly have their own characteristics for the translation as a product.

\subsection{Literature Review}

There are two problems discuss in the animal science terms such as whether equivalence can be found in SL and TL translation of animal science terms; how is the difference in both languages grammatical equivalence correlate to their meaning. Mainly, a specialized term such as animal science is using animals but they are differences for the object of study in the section of the study. In scientific translation, a translator role is attempting to have a product with natural translation since he or she has to understand the form of language commonly used in both languages, SL and TL. This is essential since the decision taken to obtain the closest equivalences in the TL. Some researchers considerably have their uniqueness of results from their analysis of 
findings such as Rusmiati (2010) who uses Baker's theory (1992) for her analysis of nouns. She found them in numbers, gender, tenses, person, voice, tense and aspect highlighted that English singular nouns preceded with articles (a, an) translated into singular in Indonesian which marked by words (suatu, satu, or esa). It means that marking of words may have varieties attach to a language show within their rules and implementation in sentences and types of text. These results have differences of markers for nouns in animal science terms because they give direct meaning to the translation. In some cases, extended nouns found giving their acceptable information to the TL as equivalences for the meaning of SL. In the article of forage lexicon defines the terms which are related to nutrition. They are considered to have a generic-specific concept in translation but context is the most important role to obtain equivalences (Aryani, 2014). She focuses on the lexicology of translation and found that words in Latin cannot be avoided in the translation including the descriptive phrases. Her article has a relationship with this study because they are also found in TL terms even though some of them in a combination of forms. However, this study has specific terms for animal science terms such as nutrition but their results are analyzed in grammatical forms. The specific use in SL effecting to their translation and translator mostly focusing on the transfer of messages especially knowledge for the terms to be understood by the target readers. In addition, Sudirman (2016) conveys that accuracy and clarity of the message transferred from the SL into TL are important in technical translation which is characterized by three things as of lexical choice of words in TL that is related to the meaning in SL, the choice of particular words in SL change the meaning of the SL, translator's ability is essential to create new words (neologism) and words that have a lot of meaning (polysemous). In addition, he mentions that equivalence of translation concern on forms and meaning of the words, direct effect of changes in form also influence the meaning and naturalness of TL. Meanwhile, its acceptability depends on transliteration, reduplication, and shift of the intra-system. His research found that some of the plural nouns in SL translated into singular nouns in the TL and vice versa so singular and plural markers that identified numbers depend on their context of use in the English into Indonesian. In this study, some cases of the findings seem to be similar for the form and relatively different in the context of meaning because it is a concern on animal science terms of a special field. In this study, the complexity of both languages, SL and TL such as grammatical had been taken part as the consideration of translators for obtaining the equivalences. English and Indonesian have their own rules in translating the terms, especially dealing with scientific languages such as animal science terms. The SL terms do not have to be translated equally the same to the TL.

\subsection{Theoretical Framework}

Baker (2018) states that differences of cross linguistics in translation give effect to the grammatical equivalence which varies considering on the grammatical category in a country. The differences of grammatical form in one language translated into another language commonly change after it is translated from SL into the TL. The purpose is to deliver messages from the content which can be added in the form of language in TL because it does not have a similar language as the meaning in SL. These grammatical categories can be discussed as follows.

1) Numbers refer to the adaptation of grammar in SL and TL. The language in the world may not have the same category of noun and forms. In some cases, there is the change of morphology such as English that singular and plural concepts are attached on the base words i.e. fox/foxes, book/books or changes in the form of language as of child/children, man/men. It is different from Japanese, Vietnamese, and Chinese. English, for example, prefer to attach suffix with -s or -es in the noun to show the plural form i.e. my books but there is no attachment of suffix for singular such as my book, however, those words in Chinese are mentioned the same as wo-de-shu (Baker cited from Tan 1980).

2) Gender is the grammatical differences in some languages which the noun or pronoun is classified into feminine or masculine. The differences apply to nouns that refer to animate or inanimate, for example, chat for male cat meanwhile chatte for a female cat in French. In contrast, English does not differ the sex of object and animate or inanimate but it only differs from person system including its meaning for the species such as cow/bull, ewe/ram, doe/stag.

3) Person is the category of participant roles in most languages are systematically applies through the closed system of pronouns. English has pronouns system such as $I$ and we for identifying the speaker or a group of a speaker as the first pronoun, you as the second pronoun, he, she, and it as the third pronouns for identifying a person or things other than the speaker and addressee.

4) Tenses and aspect define as grammatical categories in verb form indicated from time signals and different events. English has regular and irregular verbs to decide the events including the differences of time signals for the present, past, and future. In contrast, Bali has rather a precise system of time reference for past, present, and 
future reference which is marked in order to show whether the event is connected to the present, or in a period of time but taking place on the same day, or it is separated from the present by at least one night.

Those categories are used for analyzing the animal science terms based on the result of findings. However, only numbers and gender as part of them found in the forms. These are naturally showing the differences of rules in English as SL and Indonesian as TL, especially when considering the contextual of forms meaning and how they are implied in the texts.

\section{Method}

This research was conducted in the year 2017 upto 2018 in the Faculty of Animal Science, Udayana University. Qualitative and quantitative research used to analyze the translation of animal science terms. They are collected from two books entitled Small Ruminant Production in the Humid Tropics with English as SL and its translation Produksi Kambing dan Domba di Indonesia with Indonesian as the TL. These terms analyzed descriptively based on their grammatical equivalence, the effect of meaning, and the forms of language found in the translation. They were classified based on the findings of forms and relationship to Genetics and Animal Breeding, Production, Reproduction, Nutrition, and Social Economy as the subjects of Animal science. This is based on product-oriented research (Saldanha \& O'Brien, 2013).

\subsection{Research Instruments}

Questionnaries distributed to four respondents who have background knowledge of animal science. They are classified into their evaluation of acceptability for the equivalences of terms understanding in SL and TL. There are classifications of animal science terms, meanwhile scores are shown in percentage for their acceptable and unacceptable based on the respondents' evaluation. In addition, direct interview and note taking conducted to obtain information concerning on terms meaning and equivalence of translation. Furthermore, the Indonesian Dictionary V or Kamus Besar Bahasa Indonesia V (KBBI V), the Indonesian official application online dictionary and Animal Science terms dictionary are used to explain the meaning. Sorting of terms conducted in order to obtain the terms equivalence in TL consider on their meaning for both languages.

\subsection{Research Participants}

There are four respondents used as research participants who gave their evaluation of the terms implied in the texts translated from SL into TL. They are experts of animal sciences and graduated from the university in Australia for master degree or $\mathrm{PhD}$. In addition, they understood both languages because of their experience of education and native speakers of the TL.

\section{Results}

In this study, the four respondents have given their evaluation based on their skills of both languages. The animal science terms are classified into four scopes consider on their equivalence, non-equivalence, and percentage of acceptable or unacceptable of terms. There are totally 62 terms with 16 terms related to Genetics and Animal Breeding, 20 terms related to Nutrition, 4 terms related to Production of animals, 12 terms related to Reproduction, and 10 terms related to Social Economy. The percentage of acceptable means those items can give an equal understanding of translation, meanwhile, unacceptable means that they cannot give the closest terms and meaning from SL into TL. These details are shown in the following table.

Table 1. Animal science terms evaluation

\begin{tabular}{llllll}
\hline \multirow{2}{*}{ Scope of Terms } & \multirow{2}{*}{ Equivalence } & Non-equivalence & Total & \multicolumn{2}{c}{ Percentage } \\
\cline { 5 - 6 } & & 5 & 16 & $69 \%$ & $31 \%$ \\
\hline Genetics and Animal Breeding & 11 & 2 & 20 & $90 \%$ & $10 \%$ \\
Nutrition & 18 & 1 & 4 & $75 \%$ & $25 \%$ \\
Production & 3 & 4 & 12 & $67 \%$ & $33 \%$ \\
Reproduction & 8 & 1 & 10 & $90 \%$ & $10 \%$ \\
Social Economy & 9 & 13 & 62 & & \\
\hline Total & 49 & &
\end{tabular}

The above table shows that majorly the terms are equivalence translated from SL into TL because of most of 
their percentages more than fifty percents. In fact, all of the terms are Animal Science terms eventhough they have variation of percentage. The highest evaluation of equivalence of terms are related to nutrition and social economy with $90 \%$ acceptability and $10 \%$ unacceptability, however, the lowest terms are related to reproduction with $67 \%$ and $33 \%$ unacceptable terms. In this case, significant findings of translation have given to us information that the translators of both languages have succeed to transfer messages and decided the suitable and well adapted lexicon for the terms in TL. Moreover, the analysis of grammatical equivalences is futher discussed as follows.

\section{Discussion of Grammatical Equivalence}

The grammatical equivalence was found in the translation of animal science terms from SL into TL within the concordances of their grammatical rules in both languages. The differences concept of SL plural form which seems to be translated singular form in TL did not give effect to the meaning in TL since they remain to have a similar plural meaning. Number and noun phrases with the explication of conjunction were found in the translation in which these reflect their meanings. Becher (2011) in his research also found that explication with a definition can be accepted in a translation because it is intending to give a clear explanation to the TL. Moreover, Youdeowei et al. (2012) conveys that it is common to have nouns or clusters in scientific writing. In addition, Alwi et al. (2003) states that a noun in Indonesian is explicated to the left or even to the side with its core of language and called a noun phrase. The construction of language can use a noun with an adjective and their explication combine to be a phrase. This nominal and noun phrase were found in scientific writing of animal science terms related to Genetics and Animal Breeding, Production, Reproduction, Nutrition, and Social Economy. Generally, specific of terms in SL with plural form did not have to be translated equally the same with reduplication to show the plurality in TL but they are considered on their context of meaning. This is also related to Nicolae and Marinescu (2010) opinion, they agree that all aspects of the translation such as lexical level, grammatical forms, messages, and ideas. In these cases, translators have the important role to understand the context of usage, and the languages. The result of the findings is further discussed in the following data.

\subsection{Number and Plural Meaning of Animal Science Translation}

The differences between forms and gender were found in the translation of animal science terms in SL and TL. Their results were considered to the genre of text as a scientific text. Moreover, the meaning of terms in TL has the same meaning as the form in SL. Nouns and noun phrases found in animal science terms have variation of forms because they depend on the context of languages of SL and TL which are mention as number based on the theory. These are analyzed as the following discussion which is based on the findings of translation.

\subsubsection{Noun and Noun Phrase With Plural Meaning in Terms Related to Genetics and Animal Breeding}

Animal science terms related to Genetics an Animal Breeding were found in noun and noun phrases with plural meaning. The plural terms in SL showed with the suffix $-\mathrm{s}$ but their equivalences found with variation and without reduplication. In some cases, nouns were explicated with conjunction and collectives, meanwhile, the absorption of SL terms considering the pronunciation of TL which have their scientific meanings. These can be analyzed as follows.

Table 2. Animal science terms of genetics and animal breeding

\begin{tabular}{|c|c|c|c|}
\hline \multirow{2}{*}{ SL Terms } & \multirow{2}{*}{ TL Terms } & \multicolumn{2}{|c|}{ Grammatical Catagories } \\
\hline & & SL & TL \\
\hline genotypes & genotipe & Noun & Noun \\
\hline kacang and Etawah-cross goats & $\begin{array}{l}\text { kambing Kacang dan kambing } \\
\text { Peranakan Etawah (PE) }\end{array}$ & Noun Phrase & Noun Phrase \\
\hline tropical animals & ternak tropis & Noun Phrase & Noun Phrase \\
\hline genes & gen & Noun & Noun \\
\hline animal geneticists & ahli genetik ternak & Noun Phrase & Noun Phrase \\
\hline alleles & pasangan gen & Noun & Noun Phrase \\
\hline $\begin{array}{l}\text { homozygotes for the dominant } \\
\text { allele }\end{array}$ & $\begin{array}{l}\text { individu dengan pasangan gen } \\
\text { dominan yang sama }\end{array}$ & Noun Phrase & Noun Phrase \\
\hline heterozygotes & heterozigot & Noun & Noun \\
\hline
\end{tabular}




\begin{tabular}{|c|c|c|c|}
\hline homozygous_recessives & pasangan gen resesif yang sama & Noun Phrase & Noun Phrase \\
\hline recessive non-carriers & $\begin{array}{l}\text { perkawinan resesif yang bukan } \\
\text { pembawa sifat }\end{array}$ & Noun Phrase & Noun Phrase \\
\hline eding plans & rencana pemuliaan & Noun Phrase & Noun Phrase \\
\hline
\end{tabular}

The above terms consider on the SL equivalences into TL with their plural meanings. Plural forms in SL are translated with conjunctions of TL such as dan, dengan, yang and also collective word i.e. pasangan in the TL. The term "kacang and Etawah-cross goats" translated into "kambing Kacang dan kambing Peranakan Etawah (PE)" is a noun phrase in which "goats" and "kambing" as the core of term, the SL explicated to the left but TL explicated to the right. The term "homozygotes for the dominant allele" translated into "individu dengan pasangan gen dominan yang sama" with "allele" and "individu" as the core of term. The SL explicated to the left, however, and TL explicated to the right. The term has a plural meaning even though it is not reduplicated in TL. The term "genotipe" based on KBBI V application and Srigandono (1996: p. 94) that it has the meaning of physical characteristics which cannot be seen through its performances. Actually, the term is related to gene inside the body of an animal so its effect to the progeny can be more than a single physical characteristic i.e. the posture of the body, ears characteristics, colors, milk production, etc. In addition, the term meaning of "tropical animals" translated into "ternak tropis" is more than livestock that lives in the tropical island. The term "gen" in SL or "gene" in TL has meaning refer to more than a single gene because inside the ruminant's body consists of thousands of genes. Moreover, the term "ahli genetik ternak" or "animal geneticists" means geneticist in general who can be more than one scientist that understood about animals. Then, "breeding plans" translated into "rencana pemuliaan" has plural meaning in SL and TL because the program of breeding could consist of more than one program to improve the animal production.

Special cases for the term "alleles" as a noun is translated into noun phrase "pasangan gen" with plural meanings in SL and TL since they could derive from genes of their parents either female nor male. Moreover, the noun phrases of "homozygotes for the dominant allele" translated into "individu dengan pasangan gen dominan yang sama" with bound morpheme homo- and zygotes from "homozygotes". Actually, it has plural meaning because refers to the ruminant and pairs of gene that shows inherited from their parents. This is highlighted with explication to the right in SL as mention "for the dominant allele" to show the plurality of meaning for the dominant allele which could defeat the recessive genes of the ruminants. It is similar to the term "homozygous recessives" translated into "pasangan gen resesif yang sama" are noun phrases in TL, however, it has a bound morpheme of homo- from "homozygous" in SL and both of them have plural meanings. The term "pasangan gen resesif" is the core of term which means more than one parent, neither male nor female after mating. Moreover, the words with the conjunction "yang sama" is explaining that pair of genes which are equally the same. So, it has a meaning of those genes which have similar characteristics and recessive in terms of colors, posture, etc. In contrast, the term "heterozigot" based on KBBI V application means more than one zygote formed as germs more than one zygote (ovum or sperms) with a different gene. It can be analyzed from the bound morpheme hetero- that attached to "zigot" means the abundant of zygotes. The term "rencana pemuliaan" translated from "breeding plans" classified as a noun for the improvement of the animals quality in general so it means not only one animal but more than one.

\subsubsection{Noun and Noun Phrase With Plural Meaning Related to Nutrition}

The result of animal science translation related to nutrition such as foliages, by-products for animals feeds found in noun and noun phrases. The equivalences of grammatical were found in SL and TL with the plural of meaning in confix, reduplication, and without reduplication. Most of the terms found with noun phrases in SL translated also with noun phrases in the TL. In this case of study, terms found with direct translation, combination of Latin and English in SL or Indonesian and Latin in the TL. These can be further discussed in the following table.

Table 3. Animal science terms related to nutrition

\begin{tabular}{llll}
\hline \multirow{2}{*}{ SL } & TL & \multicolumn{2}{l}{ Grammatical Catagories } \\
\cline { 3 - 4 } & & SL & TL \\
\hline concentrates & konsentrat & Noun & Noun \\
animals feed & pakan ternak & Noun Phrase & Noun Phrase
\end{tabular}




$\begin{array}{llll}\text { by-products } & \begin{array}{l}\text { limbah pertanian } \\ \text { legumes }\end{array} & \text { Noun Phrase } & \text { Noun Phrase } \\ \text { beans } & \text { kacang-kacangan } & \text { Noun } & \text { Noun Phrase } \\ \text { rations } & \text { Ransum } & \text { Noun } & \text { Noun } \\ \text { native grasses } & \text { rumput lapangan } & \text { Noun Phrase } & \text { Noun Phrase } \\ \text { food crops } & \text { tanaman pangan } & \text { Noun Phrase } & \text { Noun Phrase } \\ \text { polysacharides } & \text { polisakarida } & \text { Noun } & \text { Noun } \\ \text { native tropical grasses } & \text { rumput lokal tropis } & \text { Noun Phrase } & \text { Noun Phrase } \\ \text { legume tree foliages } & \text { daun legume pohon } & \text { Noun Phrase } & \text { Noun Phrase } \\ \text { industrial by-products } & \text { limbah industri pertanian } & \text { Noun Phrase } & \text { Noun Phrase } \\ \text { leucaena leaves } & \text { daun lamtoro } & \text { Noun Phrase } & \text { Noun Phrase } \\ \text { native grasses } & \text { rumput gajah } & \text { Noun Phrase } & \text { Noun Phrase } \\ \text { fresh foliages of gliricidia } & \text { daun gamal segar } & \text { Noun Phrase } & \text { Noun Phrase } \\ \text { gliricidia foliages } & \text { daun gliricidia } & \text { Noun Phrase } & \text { Noun Phrase } \\ \text { caliandra foliages } & \text { daun kaliandra } & \text { Noun Phrase } & \text { Noun Phrase } \\ \text { pasture } & \text { Rerumputan } & \text { Noun } & \text { Noun }\end{array}$

The above table showed that most of terms such as "animals feed" translated into "pakan ternak", "by-products" translated into "limbah pertanian", "legume tree foliages" translated into "daun legume pohon", "industrial by-products" translated into "limbah industri pertanian", and "daun gamal segar" are noun phrases. The term "pakan ternak" with the core "pakan" as the core of the SL as the translation of feed, "daun legume pohon" with the core "legume pohon" explicated to the right after the word "daun" for the translation of "legume tree foliages", "limbah industri pertanian" with the core "limbah" explicated to the right with "industri pertanian", and "daun gamal segar" with the core "daun gamal" for gliricidia which is explicated with "segar" for the translation of fresh.

Nouns and plural meaning found with the suffix $-\mathrm{s}$ in SL but without reduplication in TL to show their plurality i.e. "concentrates" translated into "konsentrat" which means the feed for ruminants were given in particular composition. This is similar to noun phrases such as "animal feeds" translated into "pakan ternak" as the varieties of feed for the ruminants. In addition, the term "by-products" translated into "limbah pertanian" also has plural meaning in SL and TL for the varieties of by-products on agriculture which is similar to "industrial-by-products" translated into "limbah industri pertanian" means the varieties of by-products from agriculture such as corn stover, sweet potato, cassava leaves, straws, etc. Moreover, "legumes" translated into "tanaman legume" is the feed for ruminants with various types of legumes such as gliricidia foliages, caliandra foliages, etc. The term "ration" translated into "ransum" has a plural meaning as feed because consists of varieties of forage (straws, cassava leaves, sesbania foliages, etc.) and "native grasses" translated into "rumput gajah" means more than a group of native grasses as feed for ruminants.

The uniqueness found in SL and TL such as "gliricidia foliages" translated into "daun gliricidia" with combination of Latin in "gliricidia" which is absorbed directly and without adaptation of spelling and pronunciation, however, the English "foliages" was adapted in the translation. There was no reduplication or mention within collective to show the plurality of meaning for the translation of "foliages" into "daun" so it seems to be singular but in fact, it has a plural meaning. This is similar to the term "fresh foliages of gliricidia" with the core "gliricidia" explicated to the left in SL found equivalence with its translation of "daun gamal segar". In addition, similar to "leucaena leaves" translated into "daun lamtoro" with a combination of Latin absorption and English but equivalence of translation was found in TL. All of those terms can still be accepted and understood as animal science terms agreed by the four respondents.

The term "native grasses" translated into "rumput gajah", even though the SL mentions in plural form but translated specifically as the local grasses for ruminants" feed and refer to be more than one piece of grass. Moreover, the term "pasture" translated into "rerumputan" equivalence with its plurality form shown from the confix in which there is additional of the prefix re- and the suffix -an attached to the base word of rumput. This 
is called collective noun in TL of Indonesian or it means a bunch of grasses in English. The special term of noun such as "beans" found equivalence translated into the form of "kacang-kacangan" because it seems to be specific types of legumes (Sesbania grandiflora, Caliandra, etc.). Alwi et. al. (2003: p.139) mentions that this term has a meaning of collectivities from its varieties. In this case, the legumes fed to the ruminants are more than a bunch because depend on the suitable composition needed for them and their condition whether only for the growth or gestation period.

\subsubsection{Noun Phrase With the Plural Meaning of Animal Science Terms Related to Production}

The animal science terms related to production found in numerals and noun phrases with plural meaning. They are related to the raising of small ruminants such as goat and sheep for the purpose of product improvement. The plural form and meaning in SL were adapted in TL as follows.

Table 4. Animal science terms related to production

\begin{tabular}{llll}
\hline SL & TL & \multicolumn{2}{l}{ Grammatical Catagories } \\
\cline { 3 - 4 } & & SL & TL \\
\hline slaughter of breeding animals & pemotongan kambing bibit & Noun Phrases & Noun Phrases \\
indoor pens & kandang tertutup & Noun Phrases & Noun Phrases \\
liveweight gains & pertambahan berat badan & Noun Phrases & Noun Phrases \\
\hline
\end{tabular}

Number of noun phrases found in terms such as "indoor pens" translated into "kandang tertutup", however, noun phrases found in SL of "slaughter of breeding animals" translated into "pemotongan kambing bibit" with their cores of "slaughter" in SL explicated to the right "of breeding animals" and the core "kambing bibit" in TL which is explicated to the left with "pemotongan". Besides, the nominal of "liveweight gains" was translated into "pertambahan berat badan" with the core "berat badan" and explicated to the left with "pertambahan". Based on the above data it has shown the plural form in suffix $-\mathrm{s}$ of SL within their plural meaning in TL. In general, the terms in TL have shown their plurality meaning based on the context i.e. "pemotongan kambing bibit" means that the possibility of slaughtering is not conducted for only one livestock but more than one, "kandang tertutup" means that indoor pen is used for livestock sheltering can be built more than one pen, and "pertambahan berat badan" means that the additional of liveweight is not only refer to one livestock but more than one.

\subsubsection{Noun and Noun Phrase With Plural Meaning Related to Reproduction}

Animal science terms related to Reproduction found in number of nouns and noun phrases with plural meaning in SL and TL. In some cases, the nouns in SL translated in the form of noun phrases for the TL but some of them equally the same form of nouns, or even both of them are noun phrases. The meaning of terms refers to small ruminants as mentioned below.

Table 5. Animal science terms related to reproduction

\begin{tabular}{llll}
\hline SL & TL & \multicolumn{2}{l}{ Grammatical Catagories } \\
\cline { 3 - 4 } & & SL & TL \\
\hline kids & anak kambing & Noun & Noun Phrase \\
weaners & ternak yang baru disapih & Noun & Noun Phrase \\
kidding/lambing intervals & interval beranak & Noun Phrase & Noun Phrase \\
interpartum intervals & interval kelahiran ternak & Noun Phrase & Noun Phrase \\
colostrums & colostrums & Noun & Noun \\
antibodies & antibodi & Noun & Noun \\
Etawah cross kids & anak kambing peranakan Etawah & Noun Phrase & Noun Phrase \\
small ruminants & ternak ruminansia kecil & Noun Phrase & Noun Phrase \\
\hline
\end{tabular}


Noun phrases were explicated as nouns in TL as of "ternak yang baru disapih" translated from "weaners". The core of this term is "ternak" explicated to the right with conjunction "yang" and followed with an adjective "baru disapih". In Indonesian a noun phrase is noun that can be followed with conjunction and noun or adjective (Alwi et al., 2003). The next term is noun phrase of "anak kambing peranakan Etawah" with the core "anak kambing" explicated to the right with "peranakan Etawah" translated from "Etawah cross kids". The equivalences were found in SL translated into TL in which the adaptation was translated without reduplication to show the plural meaning. The terms "anak kambing", "ternak yang baru disapih", "betina yang melahirkan", "anak kambing peranakan Etawah", and "ternak ruminansia kecil" in TL meaning refers not only to a single animal but more than one. Then "interval beranak" is the duration of birthing from all females of goat and sheep, however,"interval kelahiran ternak" means the duration of kidding which is particularly not only referring to one kid but more than one.

\subsubsection{Noun and Noun Phrase With Plural Meaning Related to Social-Economy}

The animal science terms related to Social-Economy found relatively the same as previous findings. Numerals and plural meaning were found in SL and TL. The numerals were found in SL and they were presented with the suffix $-\mathrm{s}$ to show the plurality of SL. In contrast, terms of translation in TL seem to have different adaptation with nouns and additional of conjunction. Both SL and TL The plurality of meaning in both languages have the orientation to farmers or breeder, and systems used for improving the production of livestock as follows.

Table 6. Animal science terms related to social economy

\begin{tabular}{llll}
\hline SL & TL & \multicolumn{2}{l}{ Grammatical Catagories } \\
\cline { 3 - 4 } & & SL & TL \\
\hline peasants & petani penggarap & Noun & Noun Phrase \\
small ruminant production & sistem produksi ternak ruminansia & Noun Phrase & Noun Phrase \\
systems & kecil & & \\
extensive systems & sistem ekstensif (diumbar) & Noun Phrase & Noun Phrase \\
systems combining arable & sistem yang dikombinasikan & Noun Phrase & Noun Phrase \\
cropping & dengan lahan pertanian & & \\
systems integrated & sistem tumpang sari & Noun Phrase & Noun Phrase \\
smallholder farmers & petani kecil & Noun Phrase & Noun Phrase \\
sheep breeders & peternak domba & Noun Phrase & Noun Phrase \\
demand curves & kurve permintaan & Noun Phrase & Noun Phrase \\
subsistence farmers & petani gurem & Noun Phrase & Noun Phrase \\
\hline
\end{tabular}

Based on the above data, "petani penggarap", "petani kecil", "petani gurem", and "peternak domba" have their meaning more than one farmer and breeder which are classified as noun phrases and numerals in TL, meanwhile, the term peasants is a noun. The remain terms are noun phrases which have number of meaning such as "sistem produksi ternak ruminansia kecil", "sistem ekstensif (diumbar)", "sistem yang dikombinasikan dengan lahan pertanian", dan "sistem tumpang sari" is the production systems for the ruminants. Each of the systems are related to the ruminants i.e. "sistem produksi ternak ruminansia kecil" consists of three systems, "sistem ekstensif (diumbar)" means the system is using numbers of livestock to be raised by giving them freedom to search for their feed, "sistem yang dikombinasikan dengan lahan pertanian" means that the system is applied with three combinations of arable cropping. They are mentioned in Mastika et al. (1993) such as roadside, communal, and arable grazing systems; tethering; cut and carry feeding. The first system is considered because the farmers or breeders do not have a place to raise their ruminants. Commonly, they raise them near the rice field after harvest by tethering because the feed available during this period are straws, weeds, grasses, and shrub around the wheat. It has a purpose to avoid ruminants enter the area which is still for plantation and not provided for grazing. Cutting and carrying system is used when the ruminants are kept in housing so the farmers or breeders have to cut i.e. grasses, shrub, etc. and carry them for the ruminants feed. Actually, this is a high-cost system for the farmers or breeders because it is needed a cost for concentrates and workers as assistance. 
There was plural meaning in the term of "sistem yang dikombinasikan dengan lahan pertanian" as noun phrases explicated to the right with the core of word "sistem" and then explained with words including its conjunction of "yang". The term "sistem tumpang sari" its plural meaning with arable cropping more than one called as tree cropping such as coconut tree, rubbers, etc.

\section{Gender of Animal Science Terms}

The gender found in animal science terms considered through their direct translation within their sex, either male or female from the SL into TL. It is mention in both languages for the purpose of giving clear information of the most traits of animals which are involved in the meaning of terms. These can be further discussed as follows.

Table 7. Translation of gender in Animal science terms

\begin{tabular}{llll}
\hline \multirow{2}{*}{ SL } & $\mathrm{TL}$ & \multicolumn{2}{l}{ Grammatical Catagories } \\
\cline { 3 - 4 } & & $\mathrm{SL}$ & $\mathrm{TL}$ \\
\hline ram carriers & pejantan pembawa sifat & Noun Phrases & Noun Phrases \\
parturient females & betina yang melahirkan & Noun Phrases & Noun Phrases \\
doe or ewe colostrums & colostrum induk kambing atau domba & Noun Phrases & Noun Phrases \\
\hline
\end{tabular}

The noun phrase found in TL term of "pejantan pembawa sifat" translated from "ram carriers" has the plural meaning similar to the SL. It refers to gender mentioned as the male of ruminant in general that can be more than one. The gender analyzed from "ram" in SL and "pejantan" in TL terms that have an equivalence of sex, moreover, "pejantan pembawa sifat" means the traits bring their characteristics from their genes of parents, especially ruminants. In addition, the term "parturient females" (SL) translated into "betina yang melahirkan" (TL) showed as noun phrases are explicated with conjunction in TL "yang" and including the gender from both languages, "females" and "betina" with their plural meaning as more than one sire that give birthing for the small ruminants. The term "doe or ewe colostrums" (SL) translated into "colostrum induk kambing atau $\boldsymbol{d o m b a " ~ ( T L ) ~ h a s ~ a ~ g r a m m a t i c a l ~ e q u i v a l e n c e ~ f r o m ~ t h e ~ m e a n i n g ~ o f ~ s i m i l a r ~ g e n d e r ~ m e n t i o n e d ~ f o r ~ t h e ~ m o t h e r ~ o f ~ t h e ~}$ small ruminants, goat and sheep showed with the words "doe or ewe" and "induk". The equivalence of term absorbed from English "colostrum" that is written in italic and combined with a direct translation "induk kambing atau domba". It showed plural meaning even though seem to be singular in TL with the conjunction "atau" but refer to more than one ruminant.

\section{Conclusion}

Grammatical rules in each language may have variation of implementation considering their use and type of text. The translation of Animal Science terms has its own forms in cross linguistics, including its meaning. It will be considered by the context use of terms as scientific text. Special combination and involvement of Latin cannot be avoided because this commonly occurs in scientific language. In some cases, a language could directly adopt the language in TL but if using Latin as a matter of lexical choice is still accepted with scientists, farmers, or practitioners who mainly using the terms. The translator has his or her decision to translate a language based on experiences and evaluation of the target readers understanding.

\section{Acknowledgments}

Thank you for the Ministry of Research and Technology for High Education, KemenRistek Dikti (Kementerian Riset dan Teknologi Pendidikan Tinggi) in Indonesia for the grants also the Institution of Research and Community Services, Lembaga Penelitian dan Pengabdian kepada Masyarakat (LPPM) of Udayana University for the support. Special thanks to all respondents and teamwork who had given supporting data for this research.

\section{References}

Alwi, H., Soenjono, D., Hans, L., \& dan Anton, M. M. (2003). Tata Bahasa Baku Bahasa Indonesia (3rd ed.). Jakarta. Penerbit: Balai Pustaka.

Aryani, I .G. A. I. (2014). Semantik dan Terjemahan Terminologi Tanaman Pakan. Pastura, 2(1), 2089-818. https://ojs.unud.ac.id/index.php/pastura/article/view/9017.

Baker, M. (2018). In Other Words. A Course Book Translation (3rd ed., pp. 97-111). Publisher: Routledge Taylor \& Francis Group. London dan New York. https://doi.org/10.4324/9781315619187 
Becher, V. (2011). Explicitation and implicitation in translation a corpus-based study of English-German and German-English translations of Business texts (Dissertation, Hamburg University).

Kamus Besar Bahasa Indonesia V (KBBI V). Online official application Indonesian dictionary (5th ed.). Badan Pengembangan dan Pembinaan Bahasa. Ministry of Education Republic of Indonesia.

Marcos, A. C., Howard, D., \& Thivierge, B. (2002). Translating Scientific Text: Practicalities and Pitfalls. Annual Meeting Reports. Science Editor, 25(6), 188.

Mastika, I. M., Suaryana, K. G., Oka, I. G. L., \& Sutrisna, I. B. (1993). Produksi Kambing dan Domba di Indonesia. Direktorat Jenderal Pendidikan Tinggi. Australian International Development Assistance Bureau. Small Ruminant Collaborative Research Support Program (US-AID). Surakarta. Penerbit: Sebelas Maret University Press.

Montgomery, S. L. (2009). English and Science: Realities and issues for translation in the age of an expanding lingua franca. The Journal of Specialized Translation, 11, 10.

Nicolae, M., \& Marinescu, R. (2010). Translating Cuture-Terminology and Communication. Synergy, 6(2), 166.

Romero, A. (2014). Exploring Veterinary Science, a little known translation specialisation. Medical Writing, 23(3), 3. https://doi.org/10.1179/2047480614Z.000000000234

Rusmiati. (2010). Grammatical Equivalence in the Indonesian Translation of J.K. Rowling's Novel: "Harry Potter and the DeathlyHallows". (Undergraduate thesis, Faculty of Languages and Arts, Semarang State University).

Saldanha, G., \& O’Brien, S. (2014). Research Methodologies in Translation Studies (p. 50). Routledge. New York. https://doi.org/10.4324/9781315760100

Srigandono, B. (1996). Kamus Istilah Peternakan (2nd ed., p. 94). Gadjah Mada University Press. Yogyakarta.

Sudirman, A. (2016). Current Issues in English-Indonesian Translation Equivalences. International Journal of Science and Research, 5(2), 1694. https://doi.org/10.21275/v5i2.NOV161482

Tomaszewska, W. M. (1993). Small Ruminants Production in the Humid Tropics. Sebelas Maret University Press. Surakarta.

Youdeowei, A., Stapleton, P., \& Obubo, R. (2012). Scientific Writing for Agricultural Research Scientists. A Training Resource Manual. Wageningen. Nederland.

\section{Copyrights}

Copyright for this article is retained by the author(s), with first publication rights granted to the journal.

This is an open-access article distributed under the terms and conditions of the Creative Commons Attribution license (http://creativecommons.org/licenses/by/4.0/). 